\title{
Correction to: Evaluation of Potential DNA-Damaging Effects of Nitenpyram and Imidacloprid in Human U937-Cells Using a New Statistical Approach to Analyse Comet Data
}

\author{
Erik Bivehed ${ }^{1}\left[\right.$ ] Anton Gustafsson ${ }^{1} \cdot$ Anders Berglund $^{2} \cdot$ Björn Hellman ${ }^{1}$ (i)
}

Published online: 17 February 2021

๑) Springer Nature B.V. 2021

\section{Correction to: Exposure and Health (2020) 12:547-554 https://doi.org/10.1007/s12403-019-00328-6}

The authors regret that in our paper it is stated that $2.5 \mathrm{mM}$ $\mathrm{NaCl}$ (lysis buffer solution) and $0.3 \mathrm{mM} \mathrm{NaOH}$ (electrophoresis buffer solutions) were used, it should of course be $2.5 \mathrm{M} \mathrm{NaCl}$ and $0.3 \mathrm{M} \mathrm{NaOH}$. Further it is stated that the S9-mix was prepared by only adding $2 \mathrm{mM} \mathrm{NADPH}$, it should of course be $2 \mathrm{mM}$ NADPH and $2 \mathrm{mM}$ NADH.

The authors would like to apologise for any inconvenience caused.
Publisher's Note Springer Nature remains neutral with regard to jurisdictional claims in published maps and institutional affiliations.

The original article can be found online at https://doi.org/10.1007/ s12403-019-00328-6.

Björn Hellman

bjorn.hellman@farmbio.uu.se

1 Department of Pharmaceutical Biosciences/Toxicology,

Uppsala University, Box 574, 75124 Uppsala, Sweden

2 Statstikakademin AB, 75321 Uppsala, Sweden 